\title{
OPTIMIZATION OF SELECTIVE WASTE COLLECTION ON CAMPUS
}

\author{
Victor Stangherlin Gomes (IC), Maria Teresa Françoso (PQ)
}

\section{Abstract}

The objective of this research is to show the relevance of planning waste collection using a Geographic Information System for route optimization. For this study, the selective waste collection containers' position at the State University of Campinas was used. Therefore, it was necessary to geo-reference the points of collection and the current routes using satellite positioning system - GNSS (Global Navigation Satellite System). In order to analyze the data, the software ArcGIS is used.

Key words: ArcGIS, GIS, selective collection

\section{Introduction}

Esri Network Analyst extension to ArcGIS can be used to find the most efficient routes for fleet vehicles, with focus on reducing overall kilometers driven and travel time. Using complex algorithms the extension calculates the best route in order to travel over a network of roads. Some of the inputs of the program include road length, vehicle speed, number of turns, traffic volume and the number of stops signs.

The work was divided in three phases: collecting the Geographic Information of all the waste collection containers spread around the Campus, inserting all the data gathered during phase one into ArcGIS, in order to build a map (Figure 1) showing the accurate location of the containers and the third phase, using the Network Analyst extension to find the best waste collection route and compare to the existent route, to see if there are any improvements in the trajectory that could adopted in the pursuance of lowering the cost and time needed to collect the waste on campus.

\section{Results and Discussion}

To determine the coordinates of the collection points, a GPS device was used, together with the softwares GPS TrackMaker and Google Earth for initial processing of the data collected and in addition the software ArcGIS 10.2 .

With the approximate location of the containers, obtained from the "Environment Division", some routes to cover all the points were established.

Carrying the GPS device and walking at constant speed next to the desired point, by clicking at the GPS device, a Waypoint was created. This process was repeated over the collection of 69 pre-set points. At the end of each day, all data, Routes, Tracks and Waypoints, were imported to the computer via the Software GPS TrackMaker using the Garmin GPS tab interface, and then saved in '.kml' format that could displayed on Google Earth and later used as an excel spreadsheet.

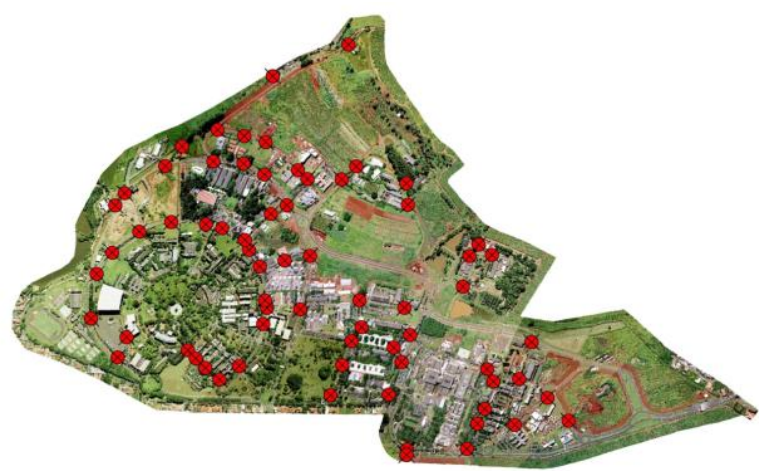

Figure 1. Map built using the software ArcGIS, showing the exact location of waste collection containers obtained from study.

\section{Conclusions}

The map built using the GPS device data and the software ArcGIS showed more accuracy then the one obtained from UNICAMP.

The next step would be to insert the streets into the software ArcGIS and using the tool Network Analyst, an optimized route would be found.

The work was discontinued due to Exchange Program funded by CAPES.

\section{Acknowledgement}

I would like to express my deepest appreciation to $\mathrm{CNPq}$ for granting Scientific Initiation scholarship linked to PIBIC. Maria Teresa Françoso for the assistance and knowledge provided, my family and girlfriend for the immense support.

\footnotetext{
1ArcGIS Content, ESRI. Disponível em: <http://www.esri.com/data /find-data> Acesso em 28 de janeiro de 2014.

'DELUQUI, K, K. Roteirização para veículo de coleta de resíduos sólidos domiciliares utilizando um Sistema de Informações Geográficas - SIG. São Carlos, 2003. 222 p. Dissertação (Mestrado em Engenharia Sanitária), Universidade de São Paulo.

${ }^{3}$ LEMES, D. C. S. S. Planejamento do Sistema de Transportes de uma Cidade de Porte Médio Auxiliado por SIG-T. Uberlândia, 2004. 125 p. Dissertação (Mestrado em Engenharia Urbana), Universidade Federal de Uberlândia.
} 